\title{
Implementasi Kebijakan Program Tahfidz Al-Qur'an Sebagai Upaya Penguatan Pendidikan Karakter Di Pondok Pesantren Al- Qur'an Putri Ibnu Katsir Jember
}

\author{
Farah Camelia ${ }^{1}$ \\ ${ }^{1}$ Institut Agama Islam Negeri (LAIN) Jember \\ e-mail: farrahahmad32386@gmail.com
}

\begin{abstract}
ABSTRAK: Pendidikan yang diharapkan akan menjadi ujung tombak kemajuan bangsa pada kenyataannya belum sepenuhnya terwujud. Ribuan Pondok Pesantren yang tersebar di seluruh daerah di Indonesia juga belum mampu mengatasi masalah degradasi karakter yang optimal. Pendidikan karakter adalah fundamental dalam pembentukan kepribadian manusia dalam rangka menciptakan generasi yang menghasilkan Allah. Salah satu sekolah berasrama yang cukup berhasil membuat program hafalan kebijakan sebagai upaya penguatan pendidikan karakter yaitu Pesantren Al-Qur'an Ibnu Katsir Jember. Melalui penelitian studi kasus dengan teknik pengumpulan data nonetnografi, pengamatan non-peserta, wawancara tidak terstruktur, dan dokumen sekunder, ditemukan bahwa pelaksanaan penghafalan kebijakan program Al-Qur'an sebagai upaya penguatan pendidikan karakter kemudian dilakukan dengan memilih program untuk ditambahkan ke Rote, ulangi hafalan, ujian bulanan, membuat menghafal dengan teman, melakukan hafalan dengan keluarga dan pengujian publik. Kegiatan ini mendorong penguatan karakter sehingga menghasilkan rasa percaya diri, toleransi, tangguh dan tahan banting, kerja sama, dan komitmen.
\end{abstract}

\begin{abstract}
Education which is expected to spearhead the progress of the nation in fact it has not been fully realized. Thousands of Islamic boarding schools spread throughout the regions in Indonesia also has not been able to overcome the problem of character degradation to the optimum. Character education is fundamental in the formation of human personality in order to create a generation that begets God. One of the boarding school which is quite successful in making the memorization program policy as an effort to strengthen character education namely the Islamic Women's Boarding School of Al-Qur'an Ibnu Katsir Jember. Through case study research with nonethnographic data collection techniques, non-participant observation, unstructured interviews, and secondary documents, It was found that the implementation of the memorization of the al-Qur'an program policy as an effort to strengthening then character education done by choosing programs to add to rote, repeat rote, monthly exams, make memorization with friends, make memorization with family and public testing. These activities encourage the strengthening of characters so as to produce self-confidence, tolerance, tough and hardiness, cooperation, and commitment.
\end{abstract}

Keyword: Implementation, Character Education, Program Policy.

\section{PENDAHULUAN}

Pendidikan merupakan sebuah upaya yang tersusun dalam prosedur pembelajaran serta bimbingan dengan tujuan agar manusia tumbuh berkembang menjadi mandiri, bertanggung jawab, kreatif, berilmu dan berkarakter mulia ${ }^{1}$. Jika kita telaah kembali UU No. 20 Tahun 2003

\footnotetext{
${ }^{1}$ Marzuki, Pendidikan Karakter Islam, (Jakarta: Amzah, 2017), hlm. 3.
} 
Pasal 3 mengarah kepada pengembangan kemampuan serta karakter agar anak didik menjadi manusia yang mulia.

Beberapa tabiat, perangai, dan perbuatan yang kurang baik dari masyarakat Indonesia di kalangan mahasiswa, anak sekolah, maupun lainnya, salah satu penyebabnya yaitu kurangnya penguatan pendidikan karakter di suatu lembaga pendidikan. Seperti fenomena yang belum lama terjadi yaitu seorang pemimpin Pondok Pesantren (Ponpes) an-Nahla Lhoksumawe menjadi pelaku pelecehan seksual kepada 15 santri laki-laki. ${ }^{2}$ Dua tahun cabuli santri pengasuh Ponpes Nurul Huda di Brebes harus masuk merasakan dinginnya lantai penjara. ${ }^{3}$ Di Gresik belasan santri disidang karena terlibat penganiayaan sesama santri. ${ }^{4}$

Fenomena pelecehan seksual yang mencoreng nama baik pelajar dan institusi pendidikan serta menjamurnya normalisasi pergaulan remaja hingga diluar batas atau biasa disebut free sex. Sebagaimana diberitakan oleh BKKBN bahwa anak usia dni sekitar usia 17-19 tahun sudah melakukan hubungan seksual di luar pernikahan. ${ }^{5}$ Beberapa kasus juga menunjukkan maraknya pelecehan terhadap guru di kelas, merampok, aksi tidak mau belajar, dan beberapa kasus lain yang jauh dari nilai-nilai karakter. ${ }^{6}$

Dari fakta di atas dapat kita ketahui bahwa beberapa orang yang terlibat kasus tersebut tidak lain adalah orang-orang yang berada di lingkungan keagamaan. Oleh karena itu pembentukan karakter semestinya dilakukan sejak awal ketika anak masih usia dini. Karakter akan lebih mudah terbentuk dan diarahkan, apabila telah berbentuk, kata Menteri Pendidikan Nasional maka akan sulit terkena provokasi sehingga karakter tidak mudah berubah. Menteri pendidikan nasional juga berharap, kepribadian bangsa terbentuk berkat terealisasinya pendidikan karakter di institusi pendidikan. ${ }^{7}$ Demi tercapainya tujuan tersebut, seyogyanya kita memikirkan dengan serius solusi terbaik berkenaan dengan problematika di atas.

Kendati pelajaran agama diajarkan di setiap pesantren, namun realitanya pendidikan karakter masih belum berhasil apabila diukur dari parameter demoralisasi masyarakat dan kejahatan yang tampak meningkat tiap tahunnya. Dari permasalahan di atas, dalam mengimplementasikan pendidikan karakter perlu kiranya penguatan dan pengembangan budaya religius yang lebih signifikan. Madrasah diniyah dan ponpes merupakan komponen terpadu dari Sistem Pendidikan Nasional. Ini secara jelas tercantum di beberapa pasal dalam UU SISDIKNAS. Kebijakan direktorat pendidikan diniyah dan ponpes memiliki visi misi pembangunan 2015-2019, salah satunya yaitu melakukan revolusi karakter bangsa. ${ }^{8}$

\footnotetext{
2 Ikhwan Hastanto, "Satu-persatu Kesaksian Santri Menguak Skandal Seks Pesantren di Aceh". diunggah 16 Juli 2019 di https://www.vice.com/id_id/article/ywy7yy/satu-per-satu-kesaksian-santri-menguak-skandal-sekspesantren-di-aceh diunduh pada tanggal 15 Oktober 2019.

3 Imam Suripto, "2 Tahun Cabuli Santri Pengasuh Ponpes di Brebes Ditangkap" diunggah 03 Januari 2019 di https://m.detik.com/news/berita-jawa-tengah/d-4369882/2-tahun-cabuli-santri-pengasuh-ponpes-di-brebesditangkap diunduh pada tanggal 15 Oktober 2019.

4 Sugiyono, "Belasan Santri di Gresik Disidang Karena Diduga Terlibat Penganiayaan Sesama Santri" diunggah 16 April 2019 di http://www.google.com/amp/s/surabaya.tribunnews.com/amp/2019/04/16/awal-kasusbelasan-santri-di-gresik-disidang-karena-diduga-terlibat-penganiayaan-sesama-santri diunduh pada tanggal 15 Oktober 2019.

${ }^{5} \mathrm{Ayu}$ Rachmaningtyas, "BKKBN: Usia 17-19 tahun terbanyak pelaku free sex" di https://www.google.com/amp/s/nasional/sindonews.com/newsread/739032/15/bkkbn-usia-17-19-tahunterbanyak-pelaku-free-sex-1366181523.

${ }^{6}$ Sofyan Sauri, Kesalahan Anak Terdidik (Yogyakarta: Fajar Pustaka, 2006), hlm. 34.

${ }^{7}$ Heri Gunawan, Pendidikan Karakter Konsep dan implementasi (Bandung: Alfabeta, 2017), hlm. 29.

8 Kementrian Agama, Kebijakan Direktorat Pendidikan Diniyah dan Pondok Pesantren, diunduh di http://ditpdpontren.kemenag.go.id/web/.
} 
Ibnu Miskawaih berpandangan bahwa ada watak yang alami berasal dari diri seseorang dan ada watak yang terbentuk sebab latihan atau kebiasaan. ${ }^{9}$ Hal tersebut menunjukkan pada dasarnya pendidikan bukan hanya sekedar mentransfer ilmu kepada peserta didik melainkan bagaimana membimbing agar terbentuk sebuah kepribadian tertentu, sekaligus menciptakan lingkungan yang mendukung dengan harapan peserta didik terdorong untuk menumbuhkan karakter istimewa dan khasnya ketika berada di tengah-tengah masyarakat. ${ }^{10}$ Salah satunya dengan memilih program tahfidz sebagai upaya penguatan pendidikan karakter. Sebagaimana kita ketahui bersama, lembaga tahfidz al-Qur'an saat ini bukan sesuatu yang asing. Rumah tahfidz pun menjamur dimana-mana. Masyarakat menerima serta menyambut baik dengan antusias memasukkan dan memilih program tahfidz untuk putra-putrinya.

Ada banyak pondok pesantren di Jawa Timur selaku tempat tinggal peneliti, yang memiliki program hafalan al-Qur'an untuk para santri, salah satunya adalah Pondok Pesantren AlQur'an (PPA) Ibnu Katsir Jember. Alasan peneliti memilih lokasi ini karena (1) PPA Ibnu Katsir merupakan pesantren perdana di Jawa Timur yang memadukan pendidikan formal S1 dan beasiswa penuh selama 4 tahun. (2) Kualitas output yaitu hafal al-Qur'an 30 juz mutqin, lulus dengan gelar sarjana S1, mampu menggunakan bahasa Arab dan membaca kitab kuning, siap menjadi pengelola, pemimpin pesantren, mujahid dakwah dengan kemampuan manajerial dan professional leadership. (3) Seluruh santri di PPA Putri Ibnu Katsir diwajibkan menghafal al-Qur'an, sehingga selain mengampu studi Strata 1 (S1) mereka harus mengejar target hafal al-Qur'an sesuai dengan target waktu yang ditentukan oleh pihak pesantren. ${ }^{11}$

Dari berbagai pemaparan di atas penulis ingin melakukan penelitian berkenaan dengan implementasi kebijakan program tahfidz sebagai upaya penguatan pendidikan karakter, faktor pendukung dan penghambat serta strategi untuk mengatasi hambatan tersebut.

Wibawa berpendapat bahwa implementasi kebijakan termasuk aktualisasi ketentuan perihal kebijakan yang fundamental, biasanya tertuang dalam undang-undang, tetapi dapat pula berbentuk mandat eksekutif yang urgen atau keputusan perundangan. Demikian juga Grindle, menyatakan bahwa implementasi kebijakan pendidikan sesungguhnya tidak hanya berhubungan dengan sistem penjabaran keputusan-keputusan politik ke dalam prosedur-prosedur rutin lewat saluran-saluran birokrasi pendidikan, tetapi lebih dari itu. ${ }^{12}$

Menurut Ali Imron, tolok ukur untuk mengetahui keberhasilan sebuah kebijakan dapat dilihat pada implementasinya. Rumusan kebijakan yang sebelumnya telah dibuat, bukan sekadar berhenti sebagai rumusan saja, melainkan harus mampu dilaksanakan menurut fungsional. Sebaik apapun rumusan kebijakan, tidak ada manfaatnya jika tidak diimplementasikan menjadi sebuah program yang nyata. Sebaliknya, meskipun rumusan kebijakan terlihat sederhana, namun saat diimplementasikan menjadi sebuah program akan terasa lebih berguna. ${ }^{13}$ Dalam proses implementasi kebijakan, setidaknya terdapat tiga aktivitas utama, yakni; interpretasi, organisasi dan aplikasi. Interpretasi ialah usaha menerjemahakan makna dan esensi program sehingga dapat

${ }^{9}$ Indah Herningrum dan Muhammad Alfian, "Pendidikan Akhlak Ibnu Miskawaih", Jurnal Islamika: Jurnal Ilmuilmu Keislaman, Vol. 19 No. 1 (2019).

10 Musyanto, "Pendidikan Karakter dalam Pembelajaran Tahfidz AlquranAl-Qur'an di SDIT Iqra 1 Kota Bengkulu”, Jurnal al-Babtsu, Vol. 1 No. 1 (2016).

11 Yayasan Ibnu Katsir Jember. Kurikulum Ma'had Ibnu Katsir. Diunduh dari: https://ibnukatsir.or.id/kurikulum/. Tanggal 17 Oktober 2019.

12 Muhammad Hasbullah, Kebijakan Pendidikan (Depok: PT RAJAGRAFINDO PERSADA, 2016), hlm. 92.

13 Ali Imron, Kebijaksanaan Pendidikan di Indonesia Proses, Produk \& Masa Depannya (Jakarta: Bumi Aksara, 2012), hlm. 64 . 
diterima dan direalisasikan. Sedangkan organisasi merupakan unit atau perhimpunan yang diperuntukkan bagi program. Sementara aplikasi ialah konsekuensi pelaksanaan program yang membutuhkan adanya perlengkapan dan biaya. ${ }^{14}$

Implementasi juga dapat diukur dengan melihat prosesnya, menanyakan apakah aktualisasi program serasi dengan yang telah dirumuskan, yaitu melihat pada praktiknya, program berbasis proyek individual dan apakah program tersebut telah terlaksana. Sebelum kebijakan diaktualisasikan, perlu diuraikan secara operasional tujuan umum menjadi tujuan khusus yang lebih spesifik. Dalam penjabaran kebijakan tersebut, harus diatur sumber dana, sumber daya serta perangkat organisasi lainnya. Dalam konteks pelaksanaan kebijakan, Siagian berpendapat bahwa perlu ada atensi terhadap hal lain yaitu; 1) manusia, 2) struktur, 3) proses administrasi dan manajemen, 4) dana, dan 5) daya. Seluruh aspek tersebut dapat menjadi sebagai faktor pendukung dan penghambat dalam implementasi kebijakan.

Edward III berpendapat bahwa komunikasi, sumber saya, disposisi, dan birokrasi merupakan empat variabel yang memiliki pengaruh penting dalam proses implementasi. Subarsono menyatakan syarat sebuah implementasi menuju keberhasilan apabila implementor mengetahui langkah-langkah yang harus dilakukan. Jika tujuan dan obyek kebijakan tidak diketahui oleh kelompok sasaran atau tidak ada kejelasan, maka dapat memicu terjadinya resistensi dengan kelompok sasaran. ${ }^{15}$ Oleh sebab itu, langkah pertama yang perlu diperhatikan adalah proses komunikasi. Menurut Ali Imron, komunikasi kebijakan pendidikan ialah proses sosialisasi atas rumusan kebijakan yang telah disahkan. Terdapat dua pihak yang bersinggungan, yakni aktor perumus kebijakan dan sasaran kebijakan. Aktor perumus kebijakan berperan sebagai komunikator, sedangkan sasaran kebijakan berperan sebagai komunikan. ${ }^{16}$ Lebih lanjut, komunikasi yang baik akan menjadikan hubungan menjadi lebih sinergi dan positif, adanya rasa saling percaya, serta mencegah timbulnya konflik. ${ }^{17}$

Selanjutnya yang perlu diperhatikan dalam implementasi kebijakan yaitu adanya sumber daya. Ali Imron menegaskan, walaupun komunikasi telah dilakukan dengan konsisten, tetapi jika dalam hal ini implementor tidak mendapatkan sumber saya manusia yang cukup serta finansial yang memadai, maka proses implementasi tidak akan berjalan efektif. ${ }^{18}$ Disposisi adalah point ketiga yang turut diperhatikan oleh Edward III. Disposisi diartikan sebagai watak dan karakteristik yang dimiliki oleh implementor, seperti; komitmen, bertanggung jawab dan kejujuran. Jika implementor tidak memiliki disposisi yang cukup baik, maka proses implementasi akan terhambat dan berjalan kurang efektif. ${ }^{19}$ Variabel terakhir yaitu struktur birokrasi. Menurut Budi Winarno, salah satu aspek terpenting dalam setiap organisasi ialah adanya Standar Operasional Prosedur (SOP). SOP dijadikan sebagai pedoman dalam bertindak, serta berguna menyeragamkan tindakantindakan yang dilakukan oleh pelaksana. ${ }^{20}$ Dalam hal ini, implementasi program tahfidz dapat dilihat dari apa saja program-program yang dijalankan oleh pihak pesantren dan sejauh mana proses implementasi tersebut dilaksanakan.

\footnotetext{
${ }^{14}$ Ali Imron, Kebijaksanaan..., hlm. 66.

15 Subarsono, Analisis Kebijakan Publik Konsep, Teori dan Aplikasi (Yogyakarta: Pustaka Pelajar, 2009), hlm. 8791.

16 Ali Imron, Kebijaksanaan Pendidikan..., hlm. 59.

17 Ali Imron, Kebijaksanaan Pendidikan..., 58.

${ }^{18}$ Subarsono, Analisis Kebijakan...,hlm. 91

${ }^{19}$ Subarsono, Analisis Kebijakan...,hlm. 92.

${ }^{20}$ Budi Winarno, Kebijakan Publik. Teori dan Proses (Yogyakarta: MedPress, 2008), hlm. 204.
} 


\section{HASIL DAN PEMBAHASAN}

1. Kebijakan Program Tahfidz Sebagai Upaya Penguatan Pendidikan Karakter di PPA Putri Ibnu Katsir

Program tahfidz menjadi keunggulan disini, untuk mencapai tujuan umum yaitu menyelesaikan hafalan 30 Juz. Selain menyelesaikan hafalan, tujuan lain seperti pembentukan karakter tentu menjadi cita-cita bersama. Berikut kebijakan program tahfidz di PPA Putri Ibnu Katsir.

a) Halaqah pagi/riyadah hafalan

Halaqah pagi dilaksanakan setiap hari pukul 05.30-07.00 WIB. Setiap santri menyetorkan hafalan baru kepada ustadzah masing-masing. Ziyadah hafalan minimal 1 halaman setiap harinya. Jadi target ziyadah dalam satu bulan adalah 1 juz. Bagi santri yang tidak mencapai target akan dievaluasi oleh asatidz. Menyetorkan hafalan melatih santri memiliki sikap percaya diri. Mendengarkan hafalan pribadi adalah suatu hal yang biasa, namun memperdengarkan hafalan pribadi kepada orang lain merupakan sesuatu yang luar biasa.

b) Halaqah sore/muroja'ah hafalan

Halaqoh sore diisi dengan muroja'ah (mengulang-ulang) hafalan, dilaksanakan pukul 15.30-17.00 WIB. Hafalan yang disetorkan minimal 5 halaman setiap harinya dan disimak oleh ustadzah masing-masing. Tujuan halaqoh sore ialah untuk memperkuat hafalan-hafalan sebelumnya. Mengulang-ulang hafalan lama selain untuk menguatkan hafalan supaya tidak mudah pudar, juga membiasakan santri untuk bersikap tanggung jawab atas hafalan yang telah ia miliki.

c) Halaqoh malam

Halaqoh malam diisi dengan persiapan hafalan baru untuk disetorkan keesokan harinya. Kegiatan ini dilaksanakan pada pukul 19.30-20.30 WIB. Dengan adanya jadwal halaqoh malam, santri dapat mempersiapkan hafalan baru dengan lebih baik karena waktu telah terjadwal. Memutuskan untuk menjadi hafidzah butuh perjuangan keras dan tekat yang kuat dalam mewujudkannya. Dengan melakukan halaqoh malam, santri dilatih berkomitmen pada tujuan awal ketika masuk di pesantren ini.

d) Ujian Tahfidz bulanan

Ujian tahfidz ini dilaksanakan setiap bulan pada minggu kedua. Santri akan disimak hafalannya dari juz awal seperti juz 1 hingga juz akhir yang disetorkan. Contoh fulanah sudah selesai menyetorkan hafalan juz 1, maka yang akan diujikan adalah juz 1. Bulan berikutnya fulanah telah menyelesaikan juz 2, maka yang akan diujikan adalah juz 1 dan 2, begitu seterusnya. Hal tersebut dilakukan untuk menguatkan hafalan santri supaya hafalan-hafalan yang lalu tidak mudah hilang dari ingatan. Apabila juz yang diujikan tidak lancar maka dibaca ulang di ujian selanjutnya dan jika tidak mencapai target hafalan, santri akan dievaluasi atau dikenai sanksi. Secara implisit kegiatan ujian tahfidz bulanan melatih mental tangguh dan tahan banting. Santri harus melancarkan hafalan yang telah dimiliki, baru ia diperbolehkan naik juz berikutnya.

e) Karantina tahfidz 
Karantina dikhususkan bagi mahasiswa semester akhir yang telah menyelesaikan hafalannya. Mereka akan dikarantina selama 3 bulan khusus untuk melancarkan dan menguatkan hafalan. Kegiatan akademik di universitas maupun pesantren diliburkan terlebih dahulu, santri yang dikarantina mendapatkan pelayanan khusus selama masa tersebut.

f) Ujian tasmi' dengan teman

Awal mula program ini terealisasi yaitu pada tahun 2018 ketika angkatan I Putri akan melaksanakan wisuda al-Qur'an pertama kalinya. Setelah masa karantina selama 5 bulan selesai, kemudian ujian pertama yang harus dilakukan adalah tasmi' dengan teman. Setiap satu santri yang akan ujian, disimak oleh beberapa temannya. Santri harus membaca 20 juz pada waktu itu. Namun jumlah juz yang harus dibaca bertambah pada wisuda Juni tahun 2019 yaitu sebanyak 25 juz. Kemudian akan bertambah lagi di tahun berikutnya hingga santri sempurna membaca 30 juz al-Qur'an bil-ghaib (tanpa melihat). Apabila tidak mampu membaca sesuai ketentuan, maka santri tidak diwisuda.

g) Ujian tasmi' dengan keluarga

Tidak jauh berbeda dengan ujian tasmi' sebelumnya, hanya saja pada ujian ini kelurga dari santri yang sedang ujian yang diminta untuk mendengarkan hafalan. Keterangan jumlah juz yang dibaca sama seperti ujian sebelumnya. Ketentuan juga berlaku sebagaimana di ujian sebelumnya.

h) Uji publik

Santri dikumpulkan dalam satu majlis bersama masyarakat yang hadir disana. Kemudian masyarakat memberi pertanyaan secara acak kepada santri yang diuji. Uji publik merupakan puncak/ujian akhir bagi santri yang hendak diwisuda.

Setelah 4 tahun menghafal, menjalani ujian setiap bulan, kemudian masa karantina dan melewati tiga ujian di atas (tasmi' teman, keluarga, dan publik), hafalan santri dipastikan lancar dan kuat. Santri diharapkan menjadi pribadi yang berakhlak mulia, tangguh tahan banting, unggul, dan profesional.

2. Implementasi Kebijakan Program Tahfidz Al-Qur'an di PPA Putri Ibnu Katsir

Pemberlakuan sebuah kebijakan yang tertuang dalam aturan perundangundangan terhadap masyarakat secara ideal harus ditetapkan berdasarkan aspirasi dan kebutuhan masyarakat. Terdapat empat variabel dalam teori George C. Edward III untuk mencapai implementasi kebijakan pendidikan yang efektif, yaitu sebagai berikut:

a. Komunikasi

Sesuai dengan pengamatan peneliti, pengambilan kebijakan di pesantren ini melibatkan pimpinan, pihak kampus, pengurus pesantren, dewan pengajar dari dalam maupun luar pesantren, akan tetapi pengambilan keputusan penuh ada di tangan pimpinan. Komunikasi antara pengurus dan asatidz terus dilakukan. Sehubungan dengan program yang dijalankan, untuk mengetahui perkembangan serta evaluasi santri, pengurus dan asatidz rutin mengadakan rapat internal setiap pekan. Pesantren ini baru menginjak usia 6 tahun, mengingat usianya yang masih muda, selalu memperbaiki sistem merupakan prinsip yang dipegang oleh seluruh elemen kepengurusan. Oleh karena itu, apabila ada usulan dari wali santri, atau pengurus, maka akan dipertimbangkan dan dicoba terlebih dahulu. 
b. Sumber daya

Indikator sumber daya terdiri dari sumber saya manusia, sumber dana dan alokasi waktu. Adapun sumber daya yang terlibat dalam implementasi kebijakan program tahfidz ialah seluruh warga pesantren, meliputi; pimpinan pesantren, dewan pengajar, asatidz, pengurus, dan orang tua/wali santri. Kebijakan dapat berjalan dengan optimal berkat dukungan, kerja sama, dan doa dari seluruh komponen tersebut.

Mengingat pesantren ini adalah satu-satunya yang menggabungkan antara beasiswa S1 dan menghafal al-Qur'an 30 juz, sumber dana untuk program tahfidz ini sebagian besar dari donatur. Wali santri juga turut berperan karena tidak semua santri mendapatkan beasiswa full selama 4 tahun.

Santri yang berada di pesantren ini mayoritas adalah mahasiswa, maka alokasi waktu dalam implementasi program tahfidz disini terbagi menjadi dua, yaitu; waktu efektif di pesantren dan waktu efektif di kampus. Waktu efektif di kampus menyesuaikan dengan jadwal kuliah masing-masing dan santri diberi kebebasan untuk menghafal, baik ziyadah/menambah hafalan maupun muroja'ah/mengulang hafalan. Sedangkan waktu efektif di pesantren menyesuaikan dengan jadwal yang sudah ditetapkan oleh pengurus pesantren.

c. Sikap atau disposition

Pemilihan pengurus dan asatidz yang mumpuni di bidangnya merupakan salah satu usaha untuk mencapai tujuan dari program tahfidz tersebut. Kehadiran asatidz saat kegiatan setoran dan pelaksanaan ujian tiap bulannya sangat berpengaruh terhadap peningkatan jumlah hafalan santri. Implementasi kebijakan program tahfidz di PPA Putri Ibnu Katsir berjalan dengan konsisten karena adanya komitmen dari para pengurus dan asatidz. Peneliti mengamati kurangnya konsistensi dari para pengurus karena kesibukan yang dijalani oleh pengurus di luar pesantren.

d. Struktur birokrasi

Kebijakan program tahfidz disini bermula dari proses studi banding yang dilakukan oleh founder dan CO-founder Ibnu Katsir ke berbagai pondok tahfidz yang sudah berhasil di berbagai tempat. Semakin banyak santri dan lamanya waktu implementasi program tahfidz, tentu evaluasi serta perbaikan terus dilakukan. Pimpinan dan dewan asatidz pengampu hafalan santri dimintai pendapat mengenai program yang berjalan. Jika memerlukan perbaikan maupun perubahan, pimpinan tidak segan menanyakan langsung kepada asatidz. Dalam hal ini, pimpinan memiliki kewenangan memutuskan untuk menerima dan melanjutkan program tersebut atau menolak dan perlu kajian ulang karena alasan tertentu.

Setelah melakukan pengamatan dengan variabel-variabel di atas, dapat disimpulkan bahwa implementasi kebijakan program tahfidz al-Qur'an di PPA Putri Ibnu Katsir sebagai upaya penguatan pendidikan karakter telah didukung oleh komunikasi yang tersistem, sumberdaya manusia yang komitmen, sumber dana berasal dari berbagai lini, alokasi waktu yang maksimal serta adanya garis struktur birokrasi yang jelas.

3. Faktor Pendukung dan Penghambat Implementasi Kebijakan Program Tahfidz di PPA Putri Ibnu Katsir 
Faktor-faktor pendukung implementasi kebijakan program tahfidz antara lain:

a. Pondok bagi santri hafidz. Pondok ${ }^{21}$ merupakan faktor pendukung utama dengan adanya pondok atau asrama, maka lebih mudah dalam membina dan mendampingi santri dalam kegiatan sehari-hari.

b. Fasilitas yang nyaman, lengkap dan gratis. Fasilitas yang ada, serta beasiswa yang diberikan menjadi motivasi bagi santri untuk lebih fokus kepada hafalan alQur'an dan konsisten untuk menyelesaikan hafalan dengan mematuhi tata tertib yang ada.

c. Tersedianya buku setoran ziyadah, muroja'ah, dan ujian tasmi' yang dipantau langsung oleh asatidz. Berharap dengan adanya buku-buku tersebut, santri akan bertanggung jawab, sungguh-sungguh dan berusaha memperbaiki hafalan terusmenerus.

d. Monitoring setiap 6 bulan dan pemberian reward serta punishment. Dari evaluasi yang terus dilakukan, dapat diketahui siapa saja santri yang mencapai dan tidak mencapai target hafalan. Bagi santri yang mencapai target maka beasiswa tetap berlaku untuk semester berikutnya, akan tetapi jika target tidak tercapai maka beasiswa akan dicabut. Santri menandatangani MoU (Memorandum of Understanding) ulang, perjanjian di atas materai berkaitan dengan tambah/berkurangnya beasiswa tersebut.

e. Adanya musyrif/musyrifah serta dewan asatidz pengampu tahfidz yang mukim dan siap menyimak hafalan santri di pesantren.

f. Jadwal halaqoh tahfidz yang teratur tentu menjadi pendukung atas implementasi kebijakan program tahfidz.

Sedangkan faktor-faktor penghambat implementasi kebijakan program tahfidz sebagai upaya peningkatan pendidikan karakter di PPA Putri Ibnu Katsir, yaitu kemampuan dan kepribadian santri itu sendiri seperti kurangnya antusias mengikuti halaqah, tidak menarget muroja'ah pribadi, dan terkadang tidak hadir setoran ziyadah maupun muroja'ah.

4. Strategi Mengatasi Penghambat Implementasi Kebijakan Program Tahfidz di PPA Putri Ibnu Katsir

Strategi dalam mengatasi kendala implementasi kebijakan pendidikan karakter dilakukan melalui dua cara yakni: Pertama, pelaksanaan kegiatan tasyji' yaitu pemberian motivasi dari pengasuh yang direalisasikan setiap pekan pada hari senin. Kedua, tindak lanjut dari asatidz bagi santri yang tidak mengikuti halaqoh. Santri akan dicari ke setiap tempat di pesantren sampai ketemu, kemudian ditanya dan diberi nasihat.

\section{KESIMPULAN}

Berdasarkan deskripsi di atas, kesimpulan yang dapat ditarik yaitu: 1) Pemilihan program yang tepat dapat memudahkan tercapainya tujuan bersama. Tentunya dengan memperhatikan situasi serta kondisi santri. 2) Implementasi kebijakan program tahfidz sebagai upaya penguatan pendidikan karakter terlaksana dalam proses pencapaian hafalan santri. Berbagai program kegiatan antara lain; setoran riyadah dan muroja'ah hafalan dan berbagai ujian al-Qur'an melahirkan

${ }^{21}$ Madrasah dan asrama (tempat mengaji, belajar agama Islam). 
karakter-karakter yang mulia. 3) Faktor pendukung yaitu adanya pondok bagi santri hafidz, fasilitas yang nyaman, lengkap dan gratis, tersedianya buku setoran ziyadah, muroja'ah, dan ujian tasmi' yang dipantau langsung oleh asatidz dan monitoring, pemberian reward serta punishment. Dan jadwal halaqoh tahfidz yang teratur. Kemudian faktor penghambat yaitu kemampuan dan kepribadian santri. 4) Strategi untuk mengatasi hambatan yaitu: Pertama, pelaksanaan kegiatan tasyji' yaitu pemberian motivasi dari pengasuh. Kedua, tindak lanjut dari asatidz bagi santri yang tidak mengikuti halaqoh.

\section{REFERENSI}

Gunawan, Heri. Pendidikan Karakter Konsep dan implementasi. Bandung: Alfabeta.

Hasbullah, Muhammad. Kebijakan Pendidikan. Depok: PT RAJAGRAFINDO PERSADA. 2016.

Hastanto, Ikhwan. "Satu-persatu Kesaksian Santri Menguak Skandal Seks Pesantren di Aceh". Diunduh dari: https://www.vice.com/id_id/article/ywy7yy/satu-per-satu-kesaksiansantri-menguak-skandal-seks-pesantren-di-aceh. Tanggal 15 Oktober 2019.

Herningrum, Indah dan Muhammad Alfian, "Pendidikan Akhlak Ibnu Miskawaih", Jurnal Islamika: Jurnal Ilmu-ilmu Keislaman, Vol. 19 No. 1 (2019).

Imron, Ali. Kebijaksanaan Pendidikan di Indonesia Proses, Produk \& Masa Depannya. Jakarta: Bumi Aksara. 2012.

Kementrian Agama. Kebijakan Direktorat Pendidikan Diniyah dan Pondok Pesantren. Diunduh dari: http://ditpdpontren.kemenag.go.id/web/.

Musyanto. "Pendidikan Karakter dalam Pembelajaran Tahfidz AlquranAl-Qur'an di SDIT Iqra 1 Kota Bengkulu”, Jurnal al-Bahtsu, Vol. 1 No. 1 (2016).

Rachmaningtyas, Ayu. "BKKBN: Usia 17-19 tahun terbanyak pelaku free sex'https://www.google.com/amp/s/nasional/sindonews.com/newsread/739032/15/b kkbn-usia-17-19-tahun-terbanyak-pelaku-free-sex-1366181523. Tanggal 05 Desember 2019.

Sauri, Sofyan. Kesalahan Anak Terdidik. Yogyakarta: Fajar Pustaka. 2006.

Subarsono, Analisis Kebijakan Publik Konsep, Teori dan Aplikasi. Yogyakarta: Pustaka Pelajar. 2009.

Sugiyono. "Belasan Santri di Gresik Disidang Karena Diduga Terlibat Penganiayaan Sesama Santri”. Diunduh dari: http://www.google.com/amp/s/surabaya.tribunnews.com/amp/2019/04/16/awalkasus-belasan-santri-di-gresik-disidang-karena-diduga-terlibat-penganiayaan-sesama-santri. Tanggal 15 Oktober 2019 
Suripto, Imam. "2 Tahun Cabuli Santri Pengasuh Ponpes di Brebes Ditangkap”. Diunduh dari: https://m.detik.com/news/berita-jawa-tengah/d-4369882/2-tahun-cabuli-santripengasuh-ponpes-di-brebes-ditangkap. Tanggal 15 Oktober 2019.

Winarno, Budi. Kebijakan Publik Teori dan Proses. Yogyakarta: MedPress. 2008.

Yayasan Ibnu Katsir Jember. Kurikulum Ma'had Ibnu Katsir. Diunduh dari: https://ibnukatsir.or.id/kurikulum/. Tanggal 17 Oktober 2019. 